\title{
An asymmetric dihydroxylation route to (R)-(-)-octopamine, (R)-(-)-tembamide and (R)-(-)-aegeline
}

\author{
Ramalingam Sadyandy, Rodney A. Fernandes, and Pradeep Kumar* \\ Division of Organic Chemistry: Technology, National Chemical Laboratory, Pune-411008, India
} E-mail: tripathi@dalton.ncl.res.in

\author{
Dedicated to Dr. A. V. Rama Rao on the occasion of his $70^{\text {th }}$ birthday \\ (received 7 Jul 04; accepted 12 Aug 04; published on the web 24 Aug 04)
}

\begin{abstract}
A simple and efficient asymmetric synthesis of $(R)$-(-)-octopamine 1, $(R)$-(-)-tembamide 2 and $(R)-(-)$-aegeline $\mathbf{3}$ is described for the first time employing the Sharpless asymmetric dihydroxylation (AD) as the source of chirality. (C) 2006 Elsevier Science Ltd. All rights reserved.
\end{abstract}

Keywords: Asymmetric synthesis, dihydroxylation, octopamine, tembamide, aegeline

\section{Introduction}

$(R)-(-)$-Octopamine $\mathbf{1}$ is a potent chiral drug possessing $\beta$-adrenergic activity. ${ }^{1}(R)-(-)$ Tembamide 2 and $(R)-(-)$-aegeline $\mathbf{3}$ are used in traditional Indian medicines and have been shown to have good hypoglycemic activity. ${ }^{2}$ Recent studies have revealed that the two enantiomers of a chiral drug usually display different biological activities ${ }^{3}$ and in most of the aryl ethanolamine drugs, the biological activity resides mainly in the $(R)$-enantiomer. ${ }^{4}$ The growing need and interest in the asymmetric synthesis of these biologically useful molecules prompted us to take up their synthesis.

Various methods for the synthesis of optically active $(R)-(-)$-octopamine $1,{ }^{5}(R)-(-)$ tembamide 2 and $(R)-(-)$-aegeline $3^{6}$ have been documented. These include either tedious chemical and biological methods ${ }^{7}$ or require the costly reagents and multistep processes with overall low chemical yields. ${ }^{8}$ Recently the enzymatic reduction of $\alpha$-bromo ketones ${ }^{9 \mathrm{a}}$ and $\alpha$-azido ketones $^{9 b}$ has also been reported for their synthesis. Surprisingly there has been no report in the literature about the asymmetric synthesis of these compounds employing the Sharpless asymmetric dihydroxylation (AD) procedure. As part of our research program aimed at developing enantioselective syntheses of naturally occurring lactones, ${ }^{10 \mathrm{a}-\mathrm{c}}$ and amino alcohols, ${ }^{10 \mathrm{~d}-}$ $\mathrm{k}_{\text {and }}$ the $\mathrm{AD}$ was envisaged as a powerful tool to chiral dihydroxy compounds offering 
considerable opportunities for synthetic manipulations. Herein we report a new and highly enantioselective synthesis of $(R)-(-)$-octopamine 1, $(R)$-(-)-tembamide 2 and $(R)$-(-)-aegeline 3 employing the AD reaction as the source of chirality.
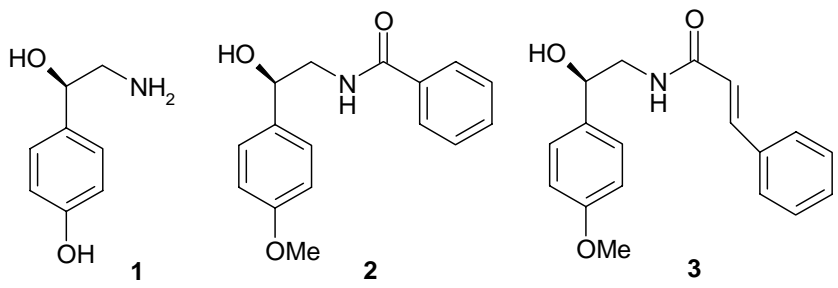

Figure 1. Structures of $(R)-(-)$-octopamine (1), $(R)-(-)$-tembamide (2), and $(R)-(-)$-aegeline (3).

\section{Results and Discussion}

Scheme 1, depicts the synthetic route to $(R)-(-)$-octopamine 1 from the commercially available 4-hydroxybenzaldehyde (4). The hydroxyl protection of $\mathbf{4}$ as benzyl ether and subsequent Wittig olefination furnished styrene 5 in excellent yield. ${ }^{10 \mathrm{i}}$ Asymmetric dihydroxylation ${ }^{11}$ of $\mathbf{5}$ using osmium tetroxide and $\mathrm{K}_{3} \mathrm{Fe}(\mathrm{CN})_{6}$ as co-oxidant in the presence of 1,4-bis(dihydroquinidin-9-Oyl)phthalazine [(DHQD) $)_{2}$ PHAL] gave the diol 6 in $94 \%$ yield. Selective conversion of the primary hydroxyl group of $\mathbf{6}$ into a tosylate was carried out using tosyl chloride in pyridine at $15^{\circ} \mathrm{C}$ to give 7 in $76 \%$ yield. The nucleophilic displacement of tosylate 7 with $\mathrm{NaN}_{3}$ afforded the azido alcohol 8, having $[\alpha]_{\mathrm{D}}{ }^{20}-68.4\left(\mathrm{c} 0.5, \mathrm{CHCl}_{3}\right)^{12}\left\{\right.$ lit. $^{5}[\alpha]_{\mathrm{D}}{ }^{20}-72.2$ (c 1.1, $\left.\left.\mathrm{CHCl}_{3}\right)\right\}$. Subsequent reduction of azide and debenzylation of 8 by catalytic hydrogenation on $10 \%$ $\mathrm{Pd}(\mathrm{OH})_{2} / \mathrm{C}$ at 60 psi furnished $(R)$-(-)-octopamine having $[\alpha]_{\mathrm{D}}{ }^{20}-35.7\left(\mathrm{c} 0.54, \mathrm{H}_{2} \mathrm{O}\right)\left\{\right.$ lit. $^{5}[\alpha]_{\mathrm{D}}{ }^{20}$ $-37.6\left(\right.$ c $\left.\left.0.56, \mathrm{H}_{2} \mathrm{O}\right)\right\}$.

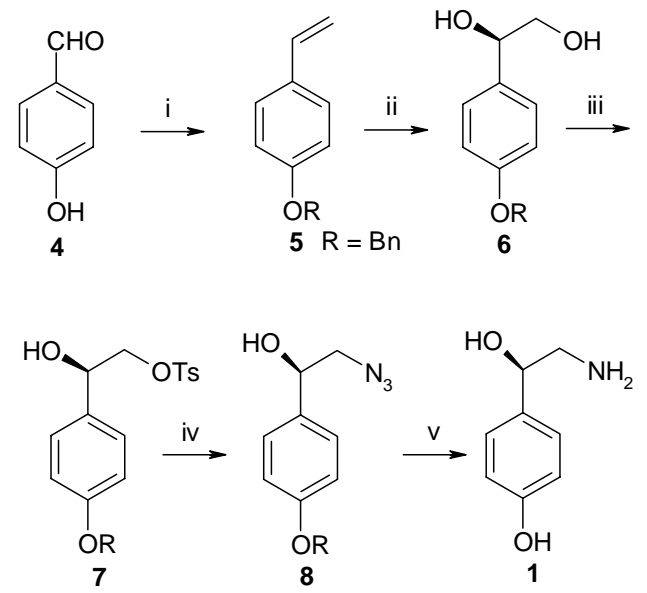

Scheme 1. (i) (a) $\mathrm{BnBr}, \mathrm{K}_{2} \mathrm{CO}_{3}$, DMF, TBAI (cat), rt, 24 h, 99\%, (b) $\mathrm{Ph}_{3} \mathrm{P}=\mathrm{CH}_{2}, \mathrm{THF}, \mathrm{rt}, 24 \mathrm{~h}$, $78 \%$; (ii) (DHQD) 2 -PHAL, $\mathrm{K}_{3} \mathrm{Fe}(\mathrm{CN})_{6}, \mathrm{~K}_{2} \mathrm{CO}_{3}, \mathrm{OsO}_{4}, t-\mathrm{BuOH} / \mathrm{H}_{2} \mathrm{O}(1: 1), 0^{\circ} \mathrm{C}, 18 \mathrm{~h}, 94 \%$; (iii) $p$-TsCl, pyridine, $-15^{\circ} \mathrm{C}, 8 \mathrm{~h}, 76 \%$; (iv) $\mathrm{NaN}_{3}, \mathrm{DMF}, 80^{\circ} \mathrm{C}, 4 \mathrm{~h}, 88 \%$; (v) $\mathrm{Pd}(\mathrm{OH})_{2} / \mathrm{C}, \mathrm{H}_{2} 60$ psi, $\mathrm{MeOH}, \mathrm{rt}, 18$ h, $86 \%$. 
The synthetic route to $(R)$-(-)-tembamide 2 and $(R)-(-)$-aegeline 3 is shown in Scheme 2. The synthesis starts from 4-methoxystyrene (9), a commercially available starting material. Asymmetric dihydroxylation of 9 with (DHQD) ${ }_{2} \mathrm{PHAL}$ ligand gave the diol $\mathbf{1 0}$ in $93 \%$ yield and $97.5 \%$ ee. $^{13}$ Selective conversion of primary hydroxyl into tosylate $\mathbf{1 1}$ and nucleophilic displacement with $\mathrm{NaN}_{3}$ gave the azido alcohol 12. Reduction of azide 12 by hydrogenation over $10 \%$ palladium on charcoal in methanol furnished the amino alcohol which on subsequent acylation with benzoyl chloride in presence of $50 \%$ aq. $\mathrm{NaOH}$ gave $(R)$-(-)-tembamide 2 in $92 \%$ yield having $[\alpha]_{\mathrm{D}}{ }^{20}-60.45\left(\mathrm{c} 0.52, \mathrm{CHCl}_{3}\right)\left\{\right.$ lit. $\left.^{9 \mathrm{~b}}[\alpha]_{\mathrm{D}}{ }^{25}-59.6\left(\mathrm{c} 0.52, \mathrm{CHCl}_{3}\right)\right\}$. In a similar manner, the reaction of amino alcohol with cinnamoyl chloride provided $(R)-(-)$-aegeline 3 in $90 \%$ yield having $[\alpha]_{\mathrm{D}}{ }^{20}-35.21\left(\mathrm{c} 0.4, \mathrm{CHCl}_{3}\right)\left\{\right.$ lit. $\left.^{9 \mathrm{~b}}[\alpha]_{\mathrm{D}}{ }^{25}-36.1\left(\mathrm{c}=0.45, \mathrm{CHCl}_{3}\right)\right\}$. The spectroscopic data of $\mathbf{2}$ and $\mathbf{3}$ are in full agreement with the literature data. ${ }^{9 \mathrm{~b}}$

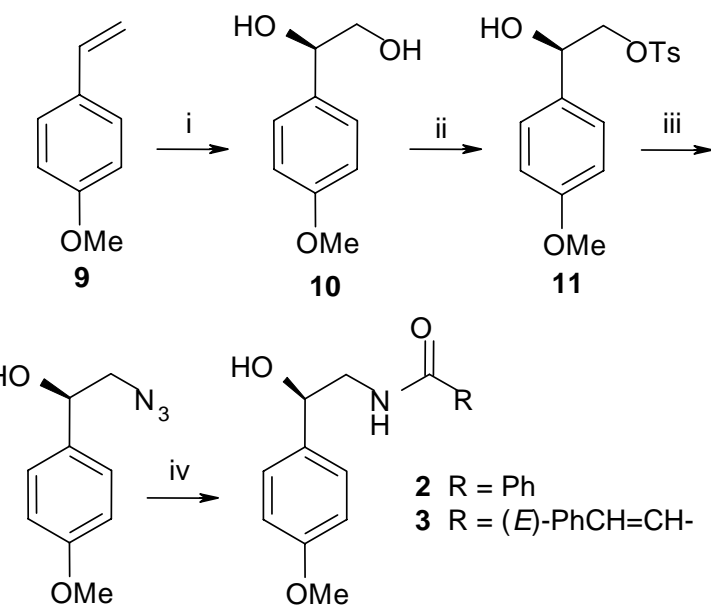

12

Scheme 2. (i) (DHQD) ${ }_{2} \mathrm{PHAL}, \mathrm{K}_{3} \mathrm{Fe}(\mathrm{CN})_{6}, \mathrm{~K}_{2} \mathrm{CO}_{3}, \mathrm{OsO}_{4}, t-\mathrm{BuOH} / \mathrm{H}_{2} \mathrm{O}(1: 1), 0^{\circ} \mathrm{C}, 18 \mathrm{~h}, 93 \%$; (ii) $p$-TsCl, pyridine, $-15^{\circ} \mathrm{C}, 8 \mathrm{~h}, 80 \%$; (iii) $\mathrm{NaN}_{3}, \mathrm{DMF}, 80^{\circ} \mathrm{C}, 4 \mathrm{~h}, 93 \%$; (iv) (a) $\mathrm{Pd} / \mathrm{C}, \mathrm{H}_{2}$, (b) $50 \%$ aq. $\mathrm{NaOH}, \mathrm{CH}_{2} \mathrm{Cl}_{2}, \mathrm{RCOCl}$, toluene, $10^{\circ} \mathrm{C}, 30 \mathrm{~min}, 90-92 \%$.

\section{Conclusions}

In summary, a practical and highly enantioselective synthesis of (-)-octopamine, (-)-tembamide and (-)-aegeline has been achieved for the first time employing the Sharpless asymmetric dihydroxylation as the source of chirality. Thus, the results described herein constitute a short and efficient route to (-)-octopamine, (-)-tembamide and (-)-aegeline. The synthetic approach can be further extended to the asymmetric synthesis of $(S)$-enantiomers via $\alpha$-dihydroxylation of 5 and 9 and following the reaction sequence, as shown in Schemes 1 and 2. 


\section{Experimental Section}

General Procedures. Solvents were purified and dried by standard procedures before use; petroleum ether of boiling range $60-80^{\circ} \mathrm{C}$ was used. Melting points are uncorrected. Optical rotations were measured using sodium D line on a JASCO P-1020 microprocessor based polarimeter. Infrared spectra were recorded on ATI MATTSON RS-1 FT-IR spectrometer. ${ }^{1} \mathrm{H}$ NMR and ${ }^{13} \mathrm{C}$ NMR spectra were recorded on Bruker AC-200 spectrometer. Mass spectra were obtained with a TSQ 70, Finningen MAT mass spectrometer. Elemental analyses were carried out on a Carlo Erba CHNS-O analyzer.

\section{4-Benzyloxystyrene 5}

This was prepared following the literature procedure. ${ }^{10 \mathrm{i}}$

(R)-1-(4-Benzyloxyphenyl)-1,2-ethanediol (6). To a solution of $\mathrm{K}_{3} \mathrm{Fe}(\mathrm{CN})_{6}(14.09 \mathrm{~g}, 42.80$ $\mathrm{mmol}), \mathrm{K}_{2} \mathrm{CO}_{3}(5.91 \mathrm{~g}, 42.80 \mathrm{mmol}$ ), (DHQD) 2 PHAL (111 mg, $0.143 \mathrm{mmol}, 1 \mathrm{~mol} \%)$ in $t$ $\mathrm{BuOH}: \mathrm{H}_{2} \mathrm{O}(1: 1,150 \mathrm{~mL})$ was added $\mathrm{OsO}_{4}(0.715 \mathrm{~mL} .0 .1 \mathrm{M}$ soln in toluene, $0.5 \mathrm{~mol} \%)$ at $0^{\circ} \mathrm{C}$. After stirring for $5 \mathrm{~min}$, 4-benzyloxystyrene $5(3 \mathrm{~g}, 14.27 \mathrm{mmol})$ was added in one portion and the reaction mixture stirred for $18 \mathrm{~h}$ at $0^{\circ} \mathrm{C}$. Solid $\mathrm{Na}_{2} \mathrm{SO}_{3}(3 \mathrm{~g})$ was added and stirred for $1 \mathrm{~h}$. The organic layer was separated and the aqueous layer extracted with EtOAc $(3 \times 100 \mathrm{~mL})$. The combined organic layers were washed (brine), dried $\left(\mathrm{Na}_{2} \mathrm{SO}_{4}\right)$ and concentrated. The residue was purified by silica gel column chromatography using petrol ether:EtOAc (7:3) as eluent to give 6 (3.276 g, 94\%) as colorless solid; $\mathrm{mp} 143-144^{\circ} \mathrm{C}$; $[\alpha]_{\mathrm{D}}{ }^{20}-39.8\left(c 0.5, \mathrm{CHCl}_{3}\right)$; IR $\left(\mathrm{CHCl}_{3}\right): v_{\max }$ $3311,2922,1613,1513,1456,1378,1248,501 \mathrm{~cm}^{-1} ;{ }^{1} \mathrm{H}$ NMR $\left(200 \mathrm{MHz}, \mathrm{CDCl}_{3}\right): \delta 1.87(\mathrm{~s}$, $2 \mathrm{H}), 3.6-3.75(\mathrm{~m}, 2 \mathrm{H}), 4.76-4.8(\mathrm{~m}, 1 \mathrm{H}), 5.07(\mathrm{~s}, 2 \mathrm{H}), 6.96(\mathrm{~d}, J=8 \mathrm{~Hz}, 2 \mathrm{H}), 7.3-7.4(\mathrm{~m}, 7 \mathrm{H})$; ${ }^{13} \mathrm{C}$ NMR $\left(50 \mathrm{MHz}, \mathrm{CDCl}_{3}\right): \delta 67.63,69.28,73.47,113.98(2 \mathrm{C}), 126.84(4 \mathrm{C}), 127.28,127.91$ (2C), 138.64, 136.14, 157.24; EIMS (m/z, \%): $243\left[\mathrm{M}^{+}-1\right]$ (13.2), 226 (12.5), 213 (9.3), 183, (40.3), 91 (100), 65 (13.8); Anal. Calcd for $\mathrm{C}_{15} \mathrm{H}_{16} \mathrm{O}_{3}$ (244.29): C, 73.75; H, 6.60. Found: C, $73.82 ; \mathrm{H}, 6.56$.

(R)-2-(O-Tosyl)-1-(4-benzyloxyphenyl)-1,2-ethanediol (7). To a solution of diol 6 (1.45 g, 5.94 mmol) in $\mathrm{CH}_{2} \mathrm{Cl}_{2}(50 \mathrm{~mL})$ was added pyridine $(0.72 \mathrm{~mL}, 8.91 \mathrm{mmol})$ and stirred for $15 \mathrm{~min}$ at room temperature. The reaction mixture was cooled to $-15^{\circ} \mathrm{C}$ and $p-\mathrm{TsCl}(1.133 \mathrm{~g}, 5.94 \mathrm{mmol})$ was added in three portions at time interval of $30 \mathrm{~min}$. The reaction mixture was stirred for $8 \mathrm{~h}$ at $-15^{\circ} \mathrm{C}$ and allowed to warm to room temperature. An aqueous solution of $\mathrm{CuSO}_{4} .5 \mathrm{H}_{2} \mathrm{O}(10 \%, 20$ $\mathrm{mL})$ and EtOAc $(100 \mathrm{~mL})$ were added and stirred for $30 \mathrm{~min}$. The organic layer was separated and the aqueous layer extracted with EtOAc $(2 \times 50 \mathrm{~mL})$. The combined organic layers were washed (brine), dried $\left(\mathrm{Na}_{2} \mathrm{SO}_{4}\right)$ and concentrated. Silica gel column chromatography of the crude product using petrol ether:EtOAc (17:3) as eluent gave 7 (1.8 g, 76\%) as colorless solid; mp 84 $85^{\circ} \mathrm{C} ;[\alpha]_{\mathrm{D}}{ }^{20}-34.7$ (c 0.5, $\left.\mathrm{CHCl}_{3}\right)$; IR $\left(\mathrm{CHCl}_{3}\right): v_{\max } 3550,2925,1613,1514,1463,1378,1173$, 815, $555 \mathrm{~cm}^{-1}$; ${ }^{1} \mathrm{H}$ NMR $\left(200 \mathrm{MHz}, \mathrm{CDCl}_{3}\right): \delta 2.08(\mathrm{~s}, 1 \mathrm{H}), 2.44(\mathrm{~s}, 3 \mathrm{H}), 3.96-4.11(\mathrm{~m}, 2 \mathrm{H})$, 4.89-4.95 (dd, $J=4,8 \mathrm{~Hz}, 1 \mathrm{H}), 5.05(\mathrm{~s}, 2 \mathrm{H}), 6.91(\mathrm{~d}, J=8 \mathrm{~Hz}, 2 \mathrm{H}), 7.20(\mathrm{~d}, J=8 \mathrm{~Hz}, 2 \mathrm{H}), 7.3-$ $7.5(\mathrm{~m}, 7 \mathrm{H}), 7.75(\mathrm{~d}, J=8 \mathrm{~Hz}, 2 \mathrm{H}) ;{ }^{13} \mathrm{C} \mathrm{NMR}\left(50 \mathrm{MHz}, \mathrm{CDCl}_{3}\right): \delta 21.28,69.65,70.93,73.99$, 
114.64 (2C), 127.17 (2C), 127.62 (3C), 128.31 (2C), 129.64 (4C), 130.89, 132.39, 136.58, 144.67, 158.49; EIMS (m/z, \%): 398 [M+] (6.2), 380 (22.8), 340 (18.4), 229 (60.6), 197 (86), 91 (100), 77 (28.7), 65 (61.9); Anal. Calcd for $\mathrm{C}_{22} \mathrm{H}_{22} \mathrm{O}_{5} \mathrm{~S}$ (398.48): C, 66.31; H, 5.56; S, 8.05. Found: C, 66.12; H, 5.65; S, 8.12.

(R)-2-Azido-1-(4-benzyloxyphenyl)ethanol (8). To a solution of 7 (618 $\mathrm{mg}, 1.55 \mathrm{mmol})$ in dry DMF $(10 \mathrm{~mL})$ was added $\mathrm{NaN}_{3}(605 \mathrm{mg}, 9.3 \mathrm{mmol})$ and stirred at $80^{\circ} \mathrm{C}$ for $4 \mathrm{~h}$. The reaction mixture was cooled to room temperature and diluted with water and EtOAc. The organic layer was separated and the aqueous layer extracted with EtOAc $(3 \times 20 \mathrm{~mL})$. The combined organic layers were washed (water and then brine) dried $\left(\mathrm{Na}_{2} \mathrm{SO}_{4}\right)$ and concentrated. The residue was purified by silica gel column chromatograpy using petrol ether:EtOAc (17:3) as eluent to give azido alcohol $8(368 \mathrm{mg}, 88 \%)$ as a colorless solid; mp $68-69^{\circ} \mathrm{C}\left[\right.$ lit. $\left.^{5} 69-70^{\circ} \mathrm{C}\right] ;[\alpha]_{\mathrm{D}}{ }^{20}-68.4(c$ $\left.0.5, \mathrm{CHCl}_{3}\right)\left\{\right.$ lit. $\left.^{5}[\alpha]_{\mathrm{D}}{ }^{20}-72.2\left(c 1.1, \mathrm{CHCl}_{3}\right)\right\} ; \mathrm{IR}\left(\mathrm{CHCl}_{3}\right): v_{\max } 3417,2926,2106,1611,1512$, 1240, 1217, 1174, 769, 668, $475 \mathrm{~cm}^{-1}$; ${ }^{1} \mathrm{H}$ NMR (200 MHz, $\left.\mathrm{CDCl}_{3}\right): \delta 1.26(\mathrm{~s}, 1 \mathrm{H}), 3.3-3.49(\mathrm{~m}$, 2H), 4.79-4.85 (dd, $J=4,8 \mathrm{~Hz}, 1 \mathrm{H}), 5.06(\mathrm{~s}, 2 \mathrm{H}), 6.95(\mathrm{~d}, J=8 \mathrm{~Hz}, 2 \mathrm{H}), 7.27$ (d, $J=8 \mathrm{~Hz}$, 2H), 7.36-7.42 (m, 5H); ${ }^{13} \mathrm{C}$ NMR (50 MHz, $\left.\mathrm{CDCl}_{3}\right): \delta 57.89,69.94,72.81,114.90(2 \mathrm{C}), 127.17$ (2C), $127.50(2 \mathrm{C}), 127.91,128.50(2 \mathrm{C}), 133.09,136.77,158.68 ; \operatorname{EIMS}(\mathrm{m} / \mathrm{z}, \%): 269\left[\mathrm{M}^{+}\right]$ (11.16), 238 (9.3), 213 (100), 185 (15.8), 170 (40.8), 91 (67.7), 77 (13.8), 65 (20.2).

(R)-(-)-Octopamine (1). To a solution of azido alcohol $8(302 \mathrm{mg}, 1.12 \mathrm{mmol})$ in EtOH (10 mL) was added $10 \% \mathrm{Pd}(\mathrm{OH})_{2}(170 \mathrm{mg})$ on charcoal at room temperature and stirred under a hydrogen atmosphere $(60 \mathrm{psi})$ for $18 \mathrm{~h}$. The catalyst was filtered on a pad of celite and the filtrate concentrated and purified by silica gel column chromatography using $n$ - $\mathrm{BuOH} / \mathrm{AcOH} / \mathrm{H}_{2} \mathrm{O}$ (3:1:1) as eluent to give $(R)-(-)$-octopamine 1 as colorless solid; $\mathrm{mp} 246-247^{\circ} \mathrm{C}\left[\right.$ lit. $\left.^{5} 245-246^{\circ} \mathrm{C}\right]$; $[\alpha]_{\mathrm{D}}{ }^{20}-35.7\left(\mathrm{c} 0.54, \mathrm{H}_{2} \mathrm{O}\right)\left\{\right.$ lit. $\left.^{5}[\alpha]_{\mathrm{D}}{ }^{20}-37.6\left(\mathrm{c} 0.56, \mathrm{H}_{2} \mathrm{O}\right)\right\}$. The spectroscopic data is in full agreement with the literature data. ${ }^{5}$

(R)-1-(4-Methoxyphenyl)-1,2-ethanediol (10). To a solution of $\mathrm{K}_{3} \mathrm{Fe}(\mathrm{CN})_{6}(22.1 \mathrm{~g}, 67.07$ $\mathrm{mmol}), \mathrm{K}_{2} \mathrm{CO}_{3}(9.26 \mathrm{~g}, 67.07 \mathrm{mmol})$, (DHQD) 2 -PHAL (174 mg, $\left.0.224 \mathrm{mmol}, 1 \mathrm{~mol} \%\right)$ in $t$ $\mathrm{BuOH}: \mathrm{H}_{2} \mathrm{O}(1: 1,200 \mathrm{~mL})$ was added $\mathrm{OsO}_{4}(1.12 \mathrm{~mL} .0 .1 \mathrm{M}$ soln in toluene, $0.5 \mathrm{~mol} \%)$ at $0^{\circ} \mathrm{C}$. After stirring for $5 \mathrm{~min}$, 4-methoxystyrene 9 (3 g, $22.36 \mathrm{mmol})$ was added in one portion and the reaction mixture stirred for $18 \mathrm{~h}$ at $0^{\circ} \mathrm{C}$. Solid $\mathrm{Na}_{2} \mathrm{SO}_{3}(3 \mathrm{~g})$ was added and stirred for $1 \mathrm{~h}$. The organic layer was separated and the aqueous layer extracted with EtOAc $(3 \times 100 \mathrm{~mL})$. The combined organic layers were washed (brine), dried $\left(\mathrm{Na}_{2} \mathrm{SO}_{4}\right)$ and concentrated. The residue was purified by silica gel column chromatography using petrol ether:EtOAc (7:3) as eluent to give 10 (3.5 g, 93\%) as colorless solid; mp $103-105^{\circ} \mathrm{C}$; $[\alpha]_{\mathrm{D}}{ }^{20}-57.7$ (c 1, $\left.\mathrm{CHCl}_{3}\right)$; IR $\left(\mathrm{CHCl}_{3}\right): v_{\max }$ 3279, 2958, 1611, 1513, $1246 \mathrm{~cm}^{-1}$; ${ }^{1} \mathrm{H}$ NMR (200 MHz, $\left.\mathrm{CDCl}_{3}\right): \delta 2.65(\mathrm{~s}, 2 \mathrm{H}), 3.6-3.7(\mathrm{~m}$, 2H), $3.81(\mathrm{~s}, 3 \mathrm{H}), 4.73-4.79(\mathrm{dd}, J=4,8 \mathrm{~Hz}, 1 \mathrm{H}), 6.92(\mathrm{~d}, J=8 \mathrm{~Hz}, 2 \mathrm{H}), 7.26(\mathrm{~d}, J=8 \mathrm{~Hz}, 2 \mathrm{H})$;

${ }^{13} \mathrm{C} \mathrm{NMR}\left(50 \mathrm{MHz}, \mathrm{CDCl}_{3}+\mathrm{DMSO}_{-}\right.$): $\delta$ 54.03, 67.04, 72.92, $112.4(2 \mathrm{C}), 126.29(2 \mathrm{C})$, 133.24, 157.68; EIMS (m/z, \%): $168\left[\mathrm{M}^{+}\right]$(3), 150 (1.5), 137 (69.3), 109 (42.3), 94 (71.53), 77 (100), 65 (38); Anal. Calcd for $\mathrm{C}_{9} \mathrm{H}_{12} \mathrm{O}_{3}$ (168.19): C, 64.27; H, 7.19. Found: C, 64.45; H, 6.91. 
(R)-2-(O-Tosyl)-1-(4-methoxyphenyl)-1,2-ethane diol (11). To a solution of diol 10 (1 g, 5.95 $\mathrm{mmol})$ in $\mathrm{CH}_{2} \mathrm{Cl}_{2}(50 \mathrm{~mL})$ was added pyridine $(0.72 \mathrm{~mL}, 8.91 \mathrm{mmol})$ and stirred for $15 \mathrm{~min}$ at room temperature. The reaction mixture was cooled to $-15^{\circ} \mathrm{C}$ and $p$ - $\mathrm{TsCl}(1.13 \mathrm{~g}, 5.95 \mathrm{mmol})$ was added in three portions at time interval of $30 \mathrm{~min}$. The reaction mixture was stirred for $8 \mathrm{~h}$ at $-15^{\circ} \mathrm{C}$ and allowed to warm to room temperature. An aqueous solution of $\mathrm{CuSO}_{4} .5 \mathrm{H}_{2} \mathrm{O}(10 \%, 20$ $\mathrm{mL})$ and EtOAc $(100 \mathrm{~mL})$ were added and stirred for $30 \mathrm{~min}$. The organic layer was separated and the aqueous layer extracted with EtOAc $(2 \times 50 \mathrm{~mL})$. The combined organic layers were washed (brine), dried $\left(\mathrm{Na}_{2} \mathrm{SO}_{4}\right)$ and concentrated. Silica gel column chromatography of the crude product using petrol ether:EtOAc (17:3) as eluent gave 11 (1.53 g, 80\%) as colorless solid; mp $78-80^{\circ} \mathrm{C} ;[\alpha]_{\mathrm{D}}{ }^{20}-53.0\left(c 1, \mathrm{CHCl}_{3}\right)$; IR $\left(\mathrm{CHCl}_{3}\right): v_{\max } 3518,2938,1612,1514,1359,1250,1176$, 971, 832, $666 \mathrm{~cm}^{-1}$; ${ }^{1} \mathrm{H}$ NMR $\left(200 \mathrm{MHz}, \mathrm{CDCl}_{3}\right): \delta 2.2(\mathrm{~s}, 1 \mathrm{H}), 2.45(\mathrm{~s}, 3 \mathrm{H}), 3.81(\mathrm{~s}, 3 \mathrm{H}), 4.06-$ $4.2(\mathrm{~m}, 2 \mathrm{H}), 4.89(\mathrm{dd}, J=4,8 \mathrm{~Hz}, 1 \mathrm{H}), 6.88(\mathrm{~d}, J=8 \mathrm{~Hz}, 2 \mathrm{H}), 7.25(\mathrm{~d}, J=8 \mathrm{~Hz}, 2 \mathrm{H}), 7.36(\mathrm{~d}, J$ $=8 \mathrm{~Hz}, 2 \mathrm{H}), 7.75(\mathrm{~d}, J=8 \mathrm{~Hz}, 2 \mathrm{H}) ;{ }^{13} \mathrm{C} \mathrm{NMR}\left(50 \mathrm{MHz}, \mathrm{CDCl}_{3}\right): \delta 21.35,55.02,71.01,74.06$, 113.76 (2C), 127.32 (2C), 127.69 (2C), 129.71 (2C), 130.56, 132.36, 144.82, 159.34; EIMS ( $\mathrm{m} / \mathrm{z}$, \%): $322\left[\mathrm{M}^{+}\right]$(5.2), 304 (42.8), 264 (8.4), 149 (63.6), 121 (100), 91 (98.7), 77 (48.7), 65 (66.9); Anal. Calcd for $\mathrm{C}_{16} \mathrm{H}_{18} \mathrm{O}_{5} \mathrm{~S}$ (322.38): C, 59.61; H, 5.62; S, 9.94. Found: C, 59.82; H, 5.52; S, 9.90.

(R)-2-Azido-1-(4-methoxyphenyl)ethanol (12). To a solution of 11 (500 mg, $1.55 \mathrm{mmol})$ in dry DMF $(10 \mathrm{~mL})$ was added $\mathrm{NaN}_{3}(605 \mathrm{mg}, 9.3 \mathrm{mmol})$ and stirred at $80^{\circ} \mathrm{C}$ for $4 \mathrm{~h}$. The reaction mixture was cooled to room temperature and diluted with water and EtOAc. The organic layer was separated and the aqueous layer extracted with EtOAc $(3 \times 20 \mathrm{~mL})$. The combined organic layers were washed (water and then brine) dried $\left(\mathrm{Na}_{2} \mathrm{SO}_{4}\right)$ and concentrated. The residue was purified by silica gel column chromatograpy using petrol ether:EtOAc (17:3) as eluent to give azido alcohol $12(278 \mathrm{mg}, 93 \%)$ as a colorless oil; $[\alpha]_{\mathrm{D}}{ }^{20}-77.11\left(c 1, \mathrm{CHCl}_{3}\right)\left\{\right.$ lit. $^{5}[\alpha]_{\mathrm{D}}{ }^{20}-117.4$ (c 1.30, $\left.\mathrm{CHCl}_{3}\right)$, lit. ${ }^{9 \mathrm{~b}}[\alpha]_{\mathrm{D}}{ }^{20}-40.1\left(c\right.$ 1.02, $\left.\left.\mathrm{CHCl}_{3}\right)\right\}$; IR $\left(\mathrm{CHCl}_{3}\right): v_{\max } 3441,2934,2105,1612$, 1513, 1250, 832, $493 \mathrm{~cm}^{-1} ;{ }^{1} \mathrm{H}$ NMR (200 MHz, $\left.\mathrm{CDCl}_{3}\right): \delta 2.18(\mathrm{~s}, 1 \mathrm{H}), 3.35-3.5(\mathrm{~m}, 2 \mathrm{H}), 3.82$ $(\mathrm{s}, 3 \mathrm{H}), 4.8-4.87(\mathrm{dd}, J=2,6 \mathrm{~Hz}, 1 \mathrm{H}), 6.94(\mathrm{~d}, J=8 \mathrm{~Hz}, 2 \mathrm{H}), 7.33(\mathrm{~d}, J=8 \mathrm{~Hz}, 2 \mathrm{H}) ;{ }^{13} \mathrm{C}$ NMR $\left(50 \mathrm{MHz}, \mathrm{CDCl}_{3}\right): \delta 55.17,57.85,72.81,113.94(2 \mathrm{C}), 127.1(2 \mathrm{C}), 132.8,159.45 ;$ EIMS (m/z, \%): $193\left[\mathrm{M}^{+}\right]$(7.16), 162 (1.3), 137 (100), 109 (45.8), 94 (43.8), 77 (47.7), 66 (23.8); Anal. Calcd for $\mathrm{C}_{9} \mathrm{H}_{11} \mathrm{O}_{2} \mathrm{~N}_{3}$ (193.2): C, 55.95; H, 5.74; N, 21.75. Found: C, 56.1; H, 5.79; N, 21.59.

(R)-(-)-Tembamide (2). To a solution of azido alcohol 12 (500 mg, $2.58 \mathrm{mmol})$ in $\mathrm{MeOH}$ (5 $\mathrm{mL})$ was added $10 \% \mathrm{Pd} / \mathrm{C}(20 \mathrm{mg})$ and the reaction mixture stirred at room temperature under hydrogen atmosphere (filled in a balloon) for $8 \mathrm{~h}$. The catalyst was removed by filtration and the filtrate concentrated to give the amino alcohol. The residue was dissolved in $\mathrm{CH}_{2} \mathrm{Cl}_{2}(4 \mathrm{~mL})$ and a solution of $50 \%$ aq $\mathrm{NaOH}(713 \mathrm{mg})$ in water $(5 \mathrm{~mL})$ was added at $0^{\circ} \mathrm{C}$ and stirred for $15 \mathrm{~min}$. To the reaction mixture was added a solution of benzoyl chloride $(0.37 \mathrm{~mL}, 3.23 \mathrm{mmol})$ in dry toluene $(2 \mathrm{~mL})$ dropwise and stirred for further $1 \mathrm{~h}$. The solvent was removed in vacuo and the residue was diluted with cold water and extracted with EtOAc $(3 \times 50 \mathrm{~mL})$. The combined organic layers were washed (brine) dried $\left(\mathrm{Na}_{2} \mathrm{SO}_{4}\right)$ and concentrated. The residue was purified by silica gel column chromatography using petrol ether:EtOAc (1:1) to give $2(645 \mathrm{mg}, 92 \%)$ as 
a colorless solid. It was further recrystalized from petrol ether:EtOAc. Mp $154-156^{\circ} \mathrm{C}\left[\right.$ lit. $^{9 b}$ $\left.\left.154-155^{\circ} \mathrm{C}\right] ;[\alpha]_{\mathrm{D}}{ }^{20}-60.45(c) 0.52, \mathrm{CHCl}_{3}\right) \quad\left\{\right.$ lit. $\left.\left.^{9 \mathrm{~b}}[\alpha]_{\mathrm{D}}{ }^{25}-59.6(c) 0.52, \mathrm{CHCl}_{3}\right)\right\}$. The spectroscopic data is in full agreement with literature data. $9 \mathrm{~b}$

(R)-(-)-Aegeline (3). Acylation of the intermediate amino alcohol with (E)-cinnamoyl chloride under similar condition as described above gave 3 as white solid in $90 \%$ yield. $\mathrm{Mp} 196-198^{\circ} \mathrm{C}$ [lit. $\left.\left.{ }^{9 b} 195-196^{\circ} \mathrm{C}\right] ;[\alpha]_{\mathrm{D}}{ }^{20}-35.21(c) 0.4, \mathrm{CHCl}_{3}\right)\left\{\right.$ lit. $\left.^{9 \mathrm{~b}}[\alpha]_{\mathrm{D}}{ }^{20}-36.1\left(c \quad 0.45, \mathrm{CHCl}_{3}\right)\right\}$. The spectroscopic data is in full agreement with literature data. ${ }^{9 b}$

\section{Acknowledgements}

R.A.F. thanks CSIR New Delhi for financial assistance. We are grateful to Dr. M. K. Gurjar for his support and encouragement. This is NCL communication No. 6668.

\section{References and Notes}

1. (a) Kappe, T.; Armstrong, M. D. J. Med. Chem. 1964, 7, 569. (b) Albonico, S. M.; Deulofeu, V. J. Chem. Soc. (C) 1967, 1327.

2. Shoeb, A.; Kapil, R. S.; Popli, S. P. Phytochemistry 1973, 12, 2071.

3. (a) Millership, J. S.; Fitzpatrick, A. Chirality 1983, 5, 573 and references therein. (b) Brittain, R. T.; Farmer, J. B.; Marshall, R. J. Br. J. Pharmacol. 1973, 48, 144. (c) Chapman, I. D.; Buchneit, K. H.; Manley, P.; Morley, J. Trends J. Pharmacol Sci. 1992, 13, 231. (d) Stinson, S. C. Chem. Eng. News 2000, 78, 59.

4. (a) Ruffolo, R. R., Jr. Tetrahedron 1991, 47, 9953. (b) Lunts, L. H. C.; Main, B. G.; Tucker, H. In Medicinal Chemistry, The Role of Organic Chemistry in Drug Research; Roberts, S. M.; Price, B. J., Ed.; Academic Press: New York, 1985; pp 49-92.

5. Cho, B. T.; Kong, S. K.; Shin, S. H. Tetrahedron: Asymmetry 2002, 13, 1209.

6. Brown, R. F. C.; Jackson, W. R.; McCarthy, T. D. Tetrahedron: Asymmetry 1993, 4, 205.

7. (a) Ikezaki, M.; Umino, N.; Gaino, M.; Aoe, K.; Iwakuma, T.; Ohishi, T. Yakugaku. Zasshi 1986, 106, 80. (b) Noguchi, K.; Irie, K. Japan Patent 79 70, 233, 1979, Chem. Abstr. 1979, 91 630. (c) Kuck, A. M.; Albonico, S. M.; Deulofeu, V. J. Chem. Soc., Section C 1967, 1327. (d) Gu, J.-X.; Zu-Yi, L.; Gou-Qiang, L. Tetrahedron 1993, 49, 5805.

8. Senuma, M.; Yamato, E.; Koumato, T.; Gaino, M.; Kawaguchi, T.; Iwakuma, T. Chem. Expt. 1989, 4, 245.

9. (a) Goswami, J.; Bezbaruah, R. L.; Goswami, A.; Borthakur, N. Tetrahedron: Asymmetry 2001, 12, 3343. (b) Yadav, J. S.; Reddy, T.; Nanda, S.; Rao, A. B. Tetrahedron: Asymmetry 2001, 12, 3381.

10. (a) Pais, G. C. G.; Fernandes, R. A.; Kumar, P. Tetrahedron 1999, 55, 13445. (b) Fernandes, R. A.; Kumar, P. Tetrahedron: Asymmetry 1999, 10, 4349. (c) Fernandes, R. A.; Kumar, P. 
Eur. J. Org. Chem. 2002, 2921. (d) Fernandes, R. A.; Kumar P. Tetrahedron: Asymmetry 1999, 10, 4797. (e) Fernandes, R. A.; Kumar, P. Eur. J. Org. Chem. 2000, 3447. (f) Fernandes, R. A.; Kumar, P. Tetrahedron Lett. 2000, 41, 10309. (g) Pandey, R. K.; Fernandes, R. A.; Kumar, P. Tetrahedron Lett. 2002, 43, 4425. (h) Fernandes, R. A.; Kumar, P. Synthesis 2003, 129. (i) Fernandes, R. A.; Bodas, M. S.; Kumar, P. Tetrahedron 2002, 58, 1223. (j) Naidu, S.V.; Kumar, P.; Tetrahedron Lett. 2003, 44, 1035. (k) Kandula, Subba Rao.;V.; Kumar, P.; Tetrahedron Lett. 2003, 44, 1957.

11. (a) Becker, H.; Sharpless, K. B. Angew. Chem., Int. Ed. 1996, 35, 448. (b) Kolb, H. C.; VanNiewenhze, M. S.; Sharpless, K. B. Chem. Rev. 1994, 94, 2483. (c) Amberg, W.; Bennani, Y. L.; Chadha, R. K.; Crispino, G. A.; Davis, W. D.; Hartung, J.; Jeeng K-S.; Ogino, Y.; Shibata, T.; Sharpless, K. B. J.Org. Chem. 1993, 58, 844.

12. The enantiomeric purity of the azido alcohol 8 is estimated to be $94 \%$ by comparison of optical rotation with the value of $[\alpha]_{\mathrm{D}}{ }^{20}-72.2\left(c 1.1, \mathrm{CHCl}_{3}\right)$ of $99 \%$ ee.

13. Weissman, S. A.; Rossen, K.; Reider, P. J. Org. Lett. 2001, 3, 2513. 